\title{
Evaluation of the Disparity Effect in the Amounts of Weathering Agents on the Archaeological Pine Wood "Pinus sp."
}

\author{
Mahmoud Ali \\ Conservation Department, Faculty of Archaeology, Luxor University, Luxor, Egypt \\ Email: dr.mahmoud.sayed82@gmail.com
}

How to cite this paper: Ali, M. (2021). Evaluation of the Disparity Effect in the Amounts of Weathering Agents on the Archaeological Pine Wood "Pinus sp.". Archaeological Discovery, 9, 135-150. https://doi.org/10.4236/ad.2021.92007

Received: March 9, 2021

Accepted: April 19, 2021

Published: April 22, 2021

Copyright $\odot 2021$ by author(s) and Scientific Research Publishing Inc. This work is licensed under the Creative Commons Attribution International License (CC BY 4.0).

http://creativecommons.org/licenses/by/4.0/

\section{(c) (i) Open Access}

\begin{abstract}
The aim of this research is to focus on the deterioration appearances of Pine wood "Pinus sp." that has been widely used as an external architectural element in Egypt. The wooden lintels in this research were exposed to the influence of weathering factors which are varying in their amounts. This variation in the amounts was reflected in the appearance of the surface, at the anatomical structure of the pine wood, and at the changes in the main components of wood. To clarify all these changes, a comparison was made between wooden lintels exposed to two kinds of environments. Some very small samples from these environments had been chosen and examined by using the digital microscope and the Scanning Electron Microscope (SEM) which clarify the surface and anatomical changes of deteriorated wood. The Fourier transform Infrared Spectroscopy (FTIR) was used also to show the extent of changes in the main wood components. The results showed a clear difference in the surface, anatomical and chemical changes in the wood at these two different environments. In the first environment with high moisture levels, the wood was damaged more than in the other environment with high-temperature levels.
\end{abstract}

\section{Keywords}

Pine Wood, Pinus sp., Lintels, Weathering, SEM, FTIR

\section{Introduction}

Wood is an essential material in archaeological and historical buildings. It was used as an architectural element and as a furniture in these buildings (Iruela, 2020). Wooden lintels, which consist of one or more pieces of wood placed above the doors and windows, are an example of these architectural elements, 
especially in these buildings built with red and adobe bricks.

Pine wood "Pinus sp." is one of the softwood types (Wiemann, 2010), it has been widely used as an architectural element in archaeological and historical buildings in Egypt. Although that the pine wood is one of the imported woods, we notice its wide spread in Egypt through different ages and in many purposes such as: ceilings, lintels, doors, windows, mashrabiyas and columns.

The aim of this research is to focus on deteriorated pine wood, which was used in making some lintels at the mausoleum of Fatma Khatun (1283-1284) (AH 682-683) wife of Sultan Qalawun. This mausoleum is situated at Al-Ashraf Street, Al-Khalifa district, Cairo, Egypt. This building needs necessary restoration works, not only for the wooden elements but for the entire building sunken in the groundwater (Figure 1).

The wooden lintels of this mausoleum are directly exposed to the surrounding weathering factors which are: moisture, temperature, sunlight, air pollutants, and wind. Also, the factor of abandonment and neglect exacerbated the deterioration aspects of the wooden elements such as the exposure of some window lintels in the outer portico to burn (Figure 2).
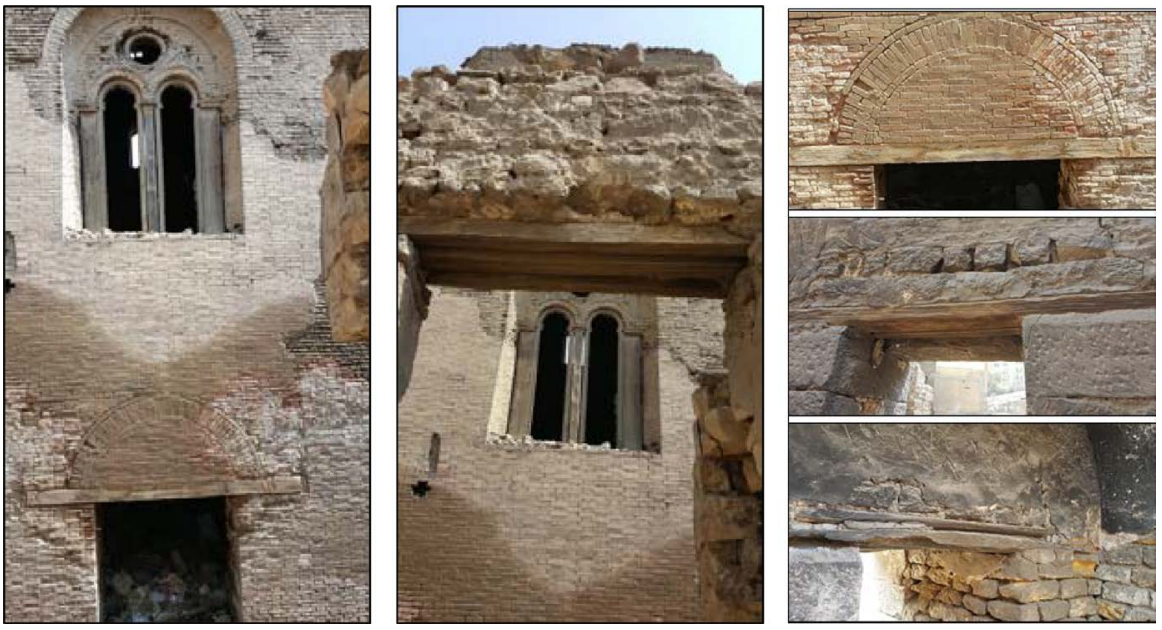

Figure 1. The wooden lintels at the mausoleum of Fatma Khatun.

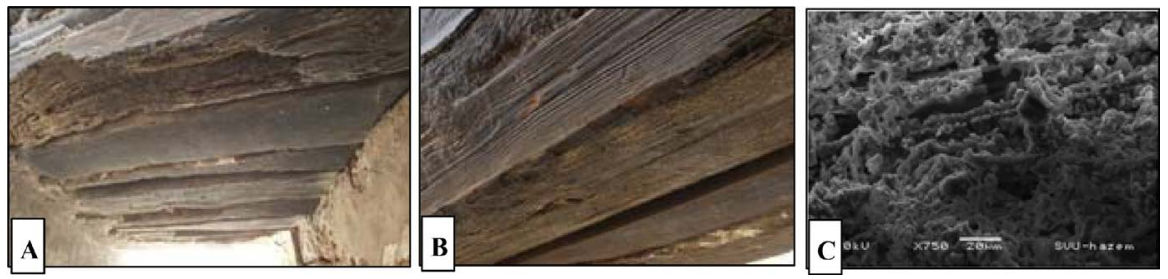

Figure 2. (A)-(C), shows the burn of some window lintels in the outer portico of Fatma Khatun mausoleum, (C) SEM micrograph. $20 \mu \mathrm{m}$.

The literature review monitored many aspects of changes spread in softwood including the Pinus sp. exposed to weathering conditions. We concluded from these researches that we can divide these changes as follows.

Surface changes: as the roughness of the wood surface, resulting from the dispar- 
ity in erosion rates of earlywood and latewood. The increasing of the earlywood erosion rate is associated with its low density (Oberhofnerová et al., 2017).

The weathered surface becomes infected with weakness and fragility, resulting from the loss of bonding between the wood fibers, which leads also to erosion and the loss of some parts from the surface (Feist, 1983; Feist, 1990). The alternation between exposure to sunlight and to the high levels of moisture leads to the spread of various cracks on the wood surface.

These cracks can sometimes lead to the split of wood, also they allow the weathering agents to penetrate to the internal parts of the wood. The cracks are considered as a suitable place for the activity of biological damage inside the archaeological wood (Teles \& Valle, 2001). The chromatic change of wood surface is a significant change resulting from the exposure of wood to the weathering factors. A previous research noted that the surface of light wood turns to a dark color, on the other side, the surface of the dark wood turns to a light color in the early phases of weathered wood. This process is associated with lignin decomposition (Oberhofnerová et al., 2017).

Anatomical changes: In general, a significant weakness in the structure of wood can be noticed in the archaeological samples treated by the previous researches. It has been observed the spread of some checks and cracks in the cell wall layers, the separation of the cell wall layers, destruction of the bordered pits (Hamed et al., 2020), destruction and loss of the middle lamella which lead to the detachment of wood cells from each other, and to the breakdown of cells walls and its layers (Hamed, 2014).

Chemical changes: Weathering factors affect the chemical compounds of wood, in particular the surface of archaeological and historical wood exposed directly to the sunlight, affecting the strength, the durability of wood, and the cohesion of the surface, In addition to the color changes, which are considered as a remarkable sign of the wood deterioration (Sandberg, 1999). The photochemical damage of the main wood compounds (lignin, cellulose, and hemicellulose) occurs by sunlight, especially UV radiation. Lignin decomposes by the UV radiation, causing the color change of archaeological wood surface (Jankowska, 2015). This process is slow and its impact is just on the thin layer of the wood surface (Sandberg, 1999).

\section{Materials and Methods}

The samples used for this research had been taken from the outdoor pine wood lintels in the mausoleum of Fatma Khatun (1283-1284) (AH 682-683). The wooden lintels were exposed to the influence of weathering factors which are varying in their amounts. Some of these lintels were exposed to the effect of weathering factors in the following sequence according to its amounts: (Moisture of "groundwater and relative humidity", sunlight, and temperature), this means that the moisture is the most influential weathering agent.

On the other hand, some of the other wooden lintels were exposed to the ef- 
fect of weathering factors in the following sequence according to its amounts: (sunlight, temperature, and relative humidity), which means that the high temperature is the most influential weathering agent. To clarify the effect of the varying in weathering factors amounts on these wooden lintels; some of the analysis methods were used, such as:

1) Digital Microscope (DM): it was used to identify the wood types by examining the Transverse Section (TS) of the wooden lintels samples prepared for that purpose.

2) Scanning Electron Microscope (SEM): it was used to clarify the surface and anatomical changes of deteriorated wood. These samples were examined by SEM (JEOL 5500 LV, South Valley University, Qena, Egypt).

3) Fourier Transform Infrared Spectra (FTIR): it was used to clarify the changes in the main chemical compounds of the archaeological pine wood (the surface layer) resulting from the effects of weathering, comparing with a control sample (Unweathered). The FTIR was used in the spectral range $400 \mathrm{~cm}^{-1}$ to $4000 \mathrm{~cm}^{-1}$ by using (FTIR Jasco. 4100, South Valley University, Qena, Egypt).

\section{Results and Discussion}

\subsection{Wood Identification}

By using the digital microscope, the examination of the wooden lintels of Fatma Khatun mausoleum, in the transverse section (TS), showed the anatomical characteristic features of the pine wood "Pinus sp.". It can be observed the growth rings, earlywood tracheid (with the thin-walled), latewood tracheid (with the thick-walled), the rays, and resin canals (Figure 3(B) \& Figure 4(B), Figure 5(B) \& Figure 5(D)). Through the examination, it was identified another kind of wood (Hardwood) wasn't broached in this research. It was used in one of the window lintels in the entry corridor of this mausoleum.
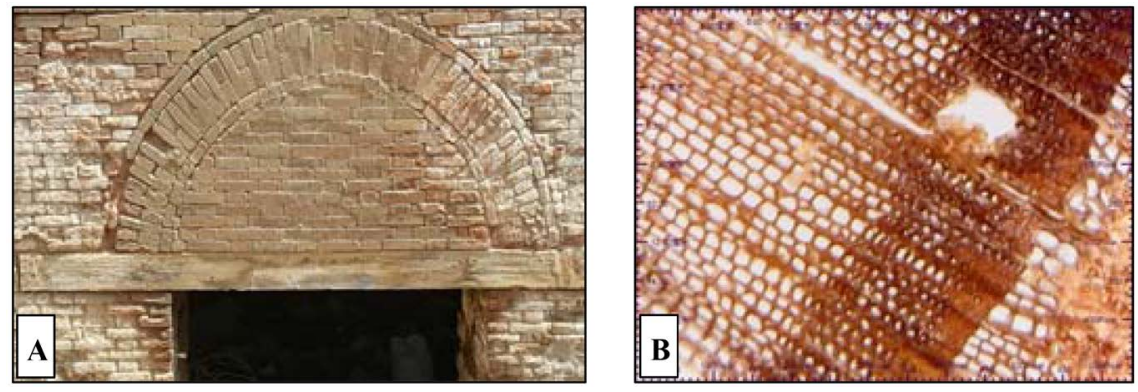

Figure 3. (A). The lintel of main door in the mausoleum dome chamber, (B). A cross-section of the pine wood (digital microscope).

\subsection{Surface and Anatomical Changes}

The pine wood (Pinus sp.) was used in the mausoleum of Fatma Khatun to make the lintels of the main door of the mausoleum dome chamber (Figure 3(A)), also it was used to make the window lintels in the outer portico and in the entry corridor of this mausoleum (Figure 4(A), Figure 5(A) \& Figure 5(C)). 

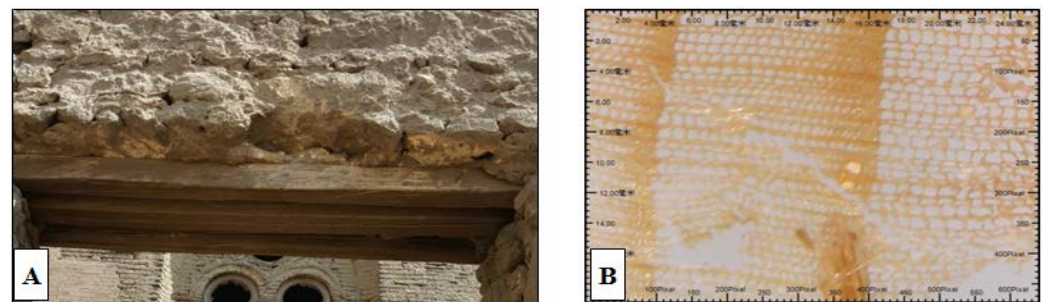

Figure 4. (A). The windows lintels in the outer portico and in the entry corridor of Fatma Khatun mausoleum, (B). A cross-section of the pine wood (digital microscope).
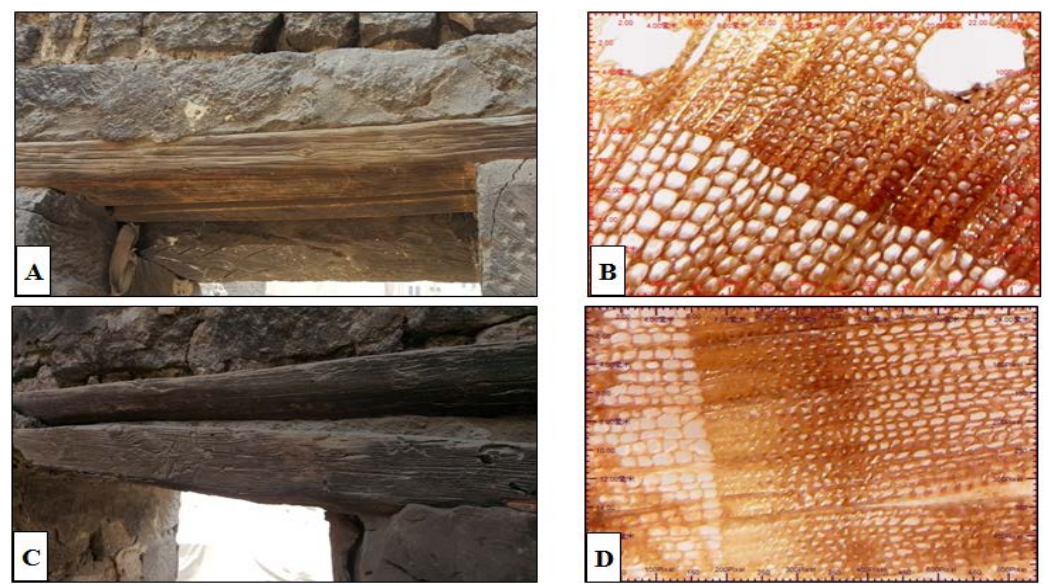

Figure 5. ((A) \& (C)). The windows lintels in the outer portico and in the entry corri-dor of FatmaKhatun mausoleum, ((B) \& (D)). A cross-section of the pine wood (digi-talmicroscope).

The lintels of the door and of the windows are exposed directly to the effect of weathering factors surrounding these lintels (Moisture, temperature, and sunlight), but in varying quantities. For example, the lintels of the windows in the outer portico and in the entry corridor are located on high ground. Therefore, the lintels of the windows in this area are exposed to the effect of weathering factors in the following sequence: (sunlight, temperature, and relative humidity), and that according to the weathering factors the more concentrated. This arrangement was reflected in the appearance of these lintels.

The pine wood used in these lintels is very dry and that led to the spread of large longitudinal cracks in the same direction of the wood fibers. These cracks extend to the edge of these lintels (Figure 6(C) \& Figure 7(B)). On the other side, we can observe the spread of fine cracks in the cell wall layers and also that there are many separations along the longitudinal axis of the wood cells (Figure 8). There are also some splits and fibers breaks on the surface and an erosion of the lintel's edges. The cracks appear on the wood surface as a result of repeated exposure to the wetness by the sources of moisture and to the drying by the high temperatures and air (Henriques \& Azevedo, 2018).

The wood surface, directly exposed to weathering, appears uneven due to the difference in erosion rates between earlywood and latewood, and also between the knots and wood tissue (Figure 7(A) \& Figure 7(B)). We can observe also 

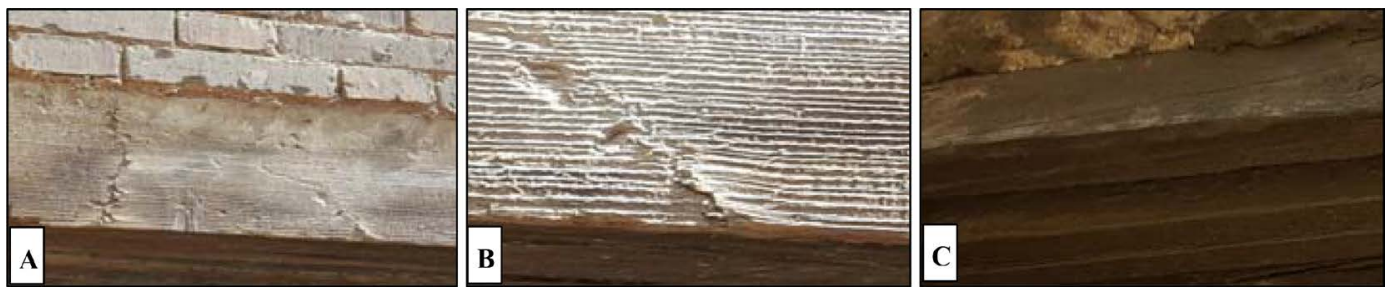

Figure 6. Spread of the different cracks on the pine wood surface, ((A), (B)) the lintel of the door in the mausoleum dome chamber, $(\mathrm{C})$ the window lintel in the outer portico.
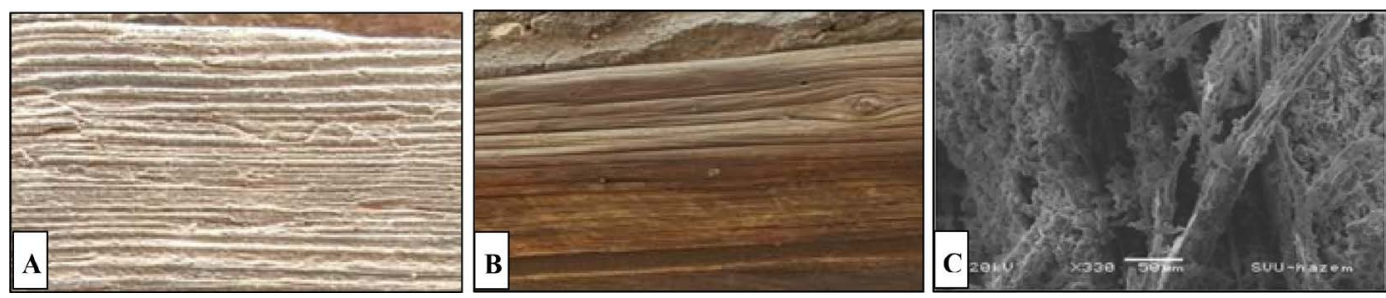

Figure 7. ((A), (B)) The window lintels in the outer portico showing the roughness of weathered wood surface, $(C)$ the accumulated dust particles between the wood fibers, SEM micrograph. $50 \mu \mathrm{m}$.
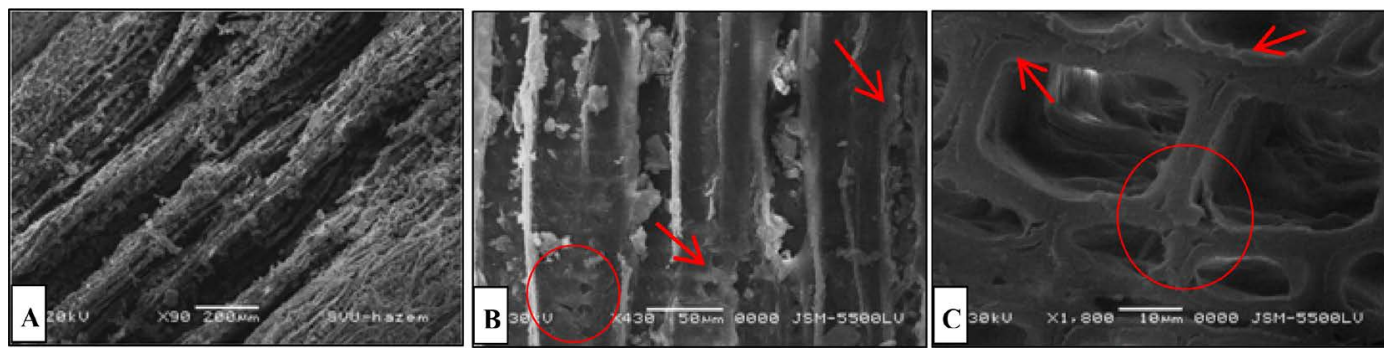

Figure 8. SEM micrographs of the window lintels in the outer portico. (A) a longitudinal section showing the fragile and detached wood fibers, (B) a radial section showing the longitudinal cracks and the degradation of bordered pits (C) A cross-section showing the cracks and the separation of cell walls layers. (bar: (A) $200 \mu \mathrm{m}$, (b) $50 \mu \mathrm{m}$, (c) $10 \mu \mathrm{m}$ ).

that there are color changes spread irregularly on the surface of wood such as the presence of light brown areas and other areas with a dark brown color. The archaeological wood takes this dark color when it's not exposed directly to the effect of rain (Sandberg, 1999). The dust particles are widespread in the surrounding area of this mausoleum and for this reason, the dust particles accumulated and stuck on the wood surface as a result of wetness and drying exchanges (Ali, 2019) (Figure 7(C)).

The lintel of the main door in the mausoleum dome chamber was exposed to the effect of weathering factors in the following sequence: (Moisture of "groundwater and relative humidity", sunlight, and temperature). This arrangement was reflected in the appearance of the wood surface. The exposure of this lintel to high moisture levels, to direct sunlight and to high temperatures, especially in summer, led to the continuous exchange of wetness and dryness processes. These continuous processes were reflected in the appearance of the wood surface which appears fragile, spongy, and with incoherent fibers resulting from the breakdown of the wood components (Sandberg, 1999) (Figure 9(C) \& Figure 10). 

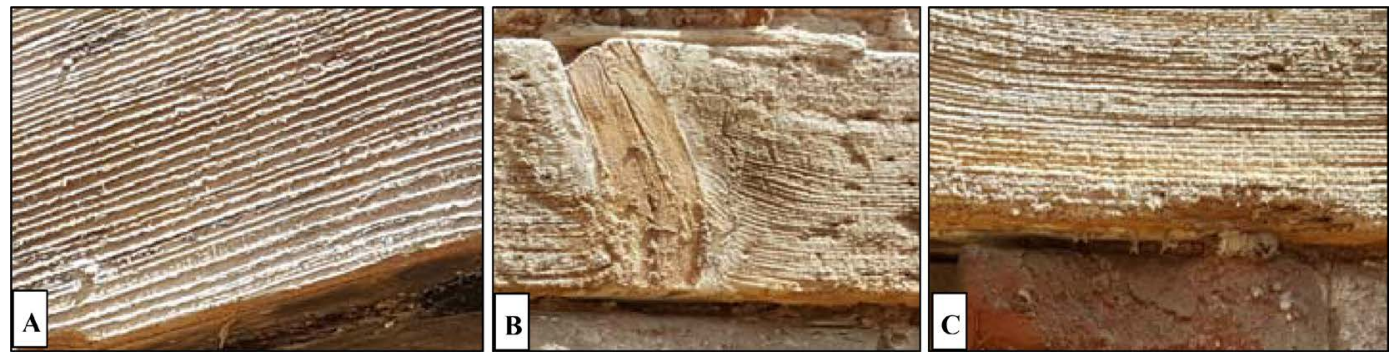

Figure 9. The lintel of the door in the mausoleum dome chamber (A) The roughness of weathered wood surface, (B) the wood knots affected by weathering, (C) the spongy appearance of the wood surface and the erosion of lintel edges.
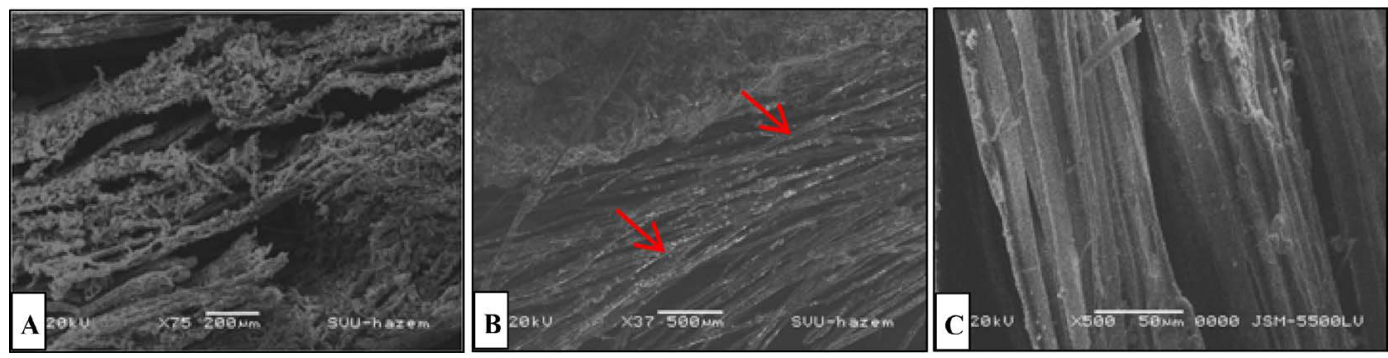

Figure 10. SEM micrographs of the door lintel in the mausoleum dome chamber, (A) a longitudinal section showing the fragile and detached wood fibers, $(B, C)$ a longitudinal section showing the detached wood tracheids. (bar: (A) $200 \mu \mathrm{m}$, (b) $500 \mu \mathrm{m}$, (C) $50 \mu \mathrm{m}$ ).

Various cracks are spread on the surface of this lintel but, the cracks which are perpendicular on the wood fibers direction are the most visible on the surface. These cracks exist just on the surface and don't penetrate to the mass of wood (Figure 6(A) \& Figure 6(B)). The cracks come as a result of the repeated swelling and shrinking processes of the surface fibers. Comparing the number and size of the spread cracks on the windows lintels with other cracks on the door lintels, it can be seen that they're macro-cracks and more numerous in the window lintels. According to previous research (Sandberg, 1999), the direction of wood surface exposed to weathering has a significant part in the determination of the number and the size of cracks on the surface. For example, the number of cracks in the radial wood surface is less than the tangential wood surface. The presence of these different cracks on the archaeological wood surface lead to the penetration of weathering factors to the interior parts of the wood which get more damaged (Ali, 2019).

One of the more visible effects of weathering on this lintel is the variation of erosion rates between earlywood and latewood. The earlywood appears as carved lines on the wood surface extending along this lintel, with variable depth (1 - 2 $\mathrm{mm}$ ). This erosion rate depends on the density of wood, therefore the low-density earlywood was the most affected by the weathering Factors (Unger et al., 2001; Williams, 2005) (Figure 9(A)). On the other side, It is also observed that the knots of wood were affected by weathering factors, as there was significant erosion, some cracks, and a loss of some of its apart (Figure 9(B)).

There are various color changes spread over the surface of this lintel. The lin- 
tel parts adjacents to walls tend to the white or gray, while the other parts tend to the brown. This gray layer was resulted from the exposure of this lintel to the high levels of moisture and the direct exposure to sunlight, also it may be caused by the effect of the fungus (Yildiz et al., 2018). A large amount of dirt particles accumulates on the surface of this lintel, which is one of the important agents of the archaeological wood surface deterioration (William, 1983) (Figure 11).

A remarkable erosion was noticed in the lintel edges, especially the parts adjacents to the wall. This loss in these parts can be explained as follows: the wooden lintels are in direct contact with the walls and absorb water mixed with salts and other large quantities of soluble building materials. Because of high temperature, these materials crystallize on the surface, and between the fibers and with the effect of wind, these materials fall out with some parts of the fragile wood from the surface (Figure 9(C)).
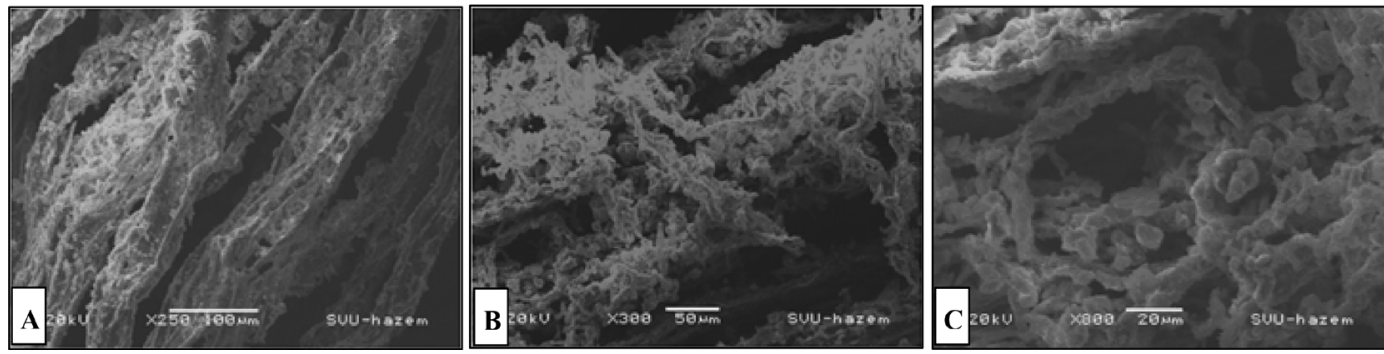

Figure 11. SEM micrographs of the door lintel in the mausoleum dome chamber, showing the detached wood fibers surrounded by dust particles. (A)-(C) longitudinal sections (bar: (A) $100 \mu \mathrm{m},(B) 50 \mu \mathrm{m},(C) 20 \mu \mathrm{m}$ ).

\subsection{FTIR Analysis}

The FTIR spectra results of the pine wood samples (S1.control sample, S2 sample from the window lintel, and S3 sample from the door lintel) shown in the (Table 1) and (Figure 12). The FTIR spectra (region range between 400 - 4000 $\mathrm{cm}^{-1}$ ) were used for the clarification of the differences between archaeological pine wood samples (weathered surface) and the control sample (unweathered sample).

By the comparison of the FTIR spectra between the archaeological pine wood samples (that were taken from the deteriorated wood surface) and the control samples (unweathered), we can understand the extent of chemical changes in the surface of this archaeological wood. This research shows a lot of changes in the bands of cellulose, hemicellulose, and lignin between the degraded wood and the control samples. It can be clarified as follows: The $\mathrm{O}-\mathrm{H}$ band stretching around $\left(3400-3420 \mathrm{~cm}^{-1}\right.$ ) shifted from $3419 \mathrm{~cm}^{-1}$ at sample S1 (the control sample) to a lower wavenumber at $3409 \mathrm{~cm}^{-1}$ for sample S2 and at $3408 \mathrm{~cm}^{-1}$ for sample S3. The absorption increased in the samples S3 and S2 as a result of the increase in the degradation of these samples (El Hadidi, 2017) and the hydroxyl groups oxidation (El-Hadidi \& Darwish, 2008). The wide band around $3420 \mathrm{~cm}^{-1}$ in the archaeological wood samples were divided into two peaks (bands): for sample S2, the two peaks appear at $3409 \mathrm{~cm}^{-1}$ and $3527 \mathrm{~cm}^{-1}$, for sample S3 the two 
Table 1. FTIR Bands of the control sample (S1), the window lintel in the outer portico (S2 sample), and the door lintel in the mausoleum dome chamber (S3 sample).

\begin{tabular}{|c|c|c|c|c|c|}
\hline \multirow{2}{*}{$\begin{array}{l}\text { Band position } \\
\quad\left(\mathrm{cm}^{-1}\right)\end{array}$} & \multirow{2}{*}{$\begin{array}{l}\text { Bands assigned } \\
\text { and Functional group }\end{array}$} & \multirow{2}{*}{ References of the FT-IR bands } & \multicolumn{3}{|c|}{ Wavenumber $\left(\mathrm{cm}^{-1}\right) /$ absorptions } \\
\hline & & & Sample S1 & Sample S2 & Sample S3 \\
\hline \multirow[t]{2}{*}{$3200-3460 \mathrm{~cm}^{-1}$} & \multirow[t]{2}{*}{$\mathrm{O}-\mathrm{H}$ stretching in carbohydrate and lignin } & \multirow[t]{2}{*}{ (Popescu et al., 2011a) } & \multirow[t]{2}{*}{$3419 / 62.41$} & $3409 / 63.15$ & \\
\hline & & & & $3527 / 67.42$ & $3527 / 65.54$ \\
\hline $2842-2935 \mathrm{~cm}^{-1}$ & $\begin{array}{l}\mathrm{C}-\mathrm{H} \text { stretching (methyl and methylene } \\
\text { groups) }\end{array}$ & (Pandey, 1999) & $2937 / 85.34$ & $2895 / 94.38$ & $2938 / 90.97$ \\
\hline \multirow[t]{2}{*}{$1731-1739 \mathrm{~cm}^{-1}$} & $\begin{array}{c}\mathrm{C}=\mathrm{O} \text { stretching (unconjugated ketones) in } \\
\text { hemicellulose }\end{array}$ & $\begin{array}{c}\text { (Shi et al., 2012; Yilgor et al., 2013; } \\
\text { Özgenç et al., 2018) }\end{array}$ & $1727 / 84.02$ & - & $1732 / 87.46$ \\
\hline & \multirow{3}{*}{ Absorbed water } & \multirow{3}{*}{ (El Hadidi \& Darwish, 2014) } & \multirow{3}{*}{$1645 / 79.18$} & $1637 / 74.41$ & $1647 / 73.54$ \\
\hline $1640 \mathrm{~cm}^{-1}$ & & & & \multirow[t]{2}{*}{$1625 / 74.51$} & $1636 / 72.89$ \\
\hline & & & & & $1624 / 72.43$ \\
\hline $1595 \mathrm{~cm}^{-1}$ & Aromatic skeletal, $\mathrm{C}=\mathrm{O}$ stretch in lignin & (Han et al., 2020) & $1592 / 84.11$ & $1595 / 86.84$ & $1594 / 87.92$ \\
\hline $1506-1515 \mathrm{~cm}^{-1}$ & $\mathrm{C}=\mathrm{C}$ stretching, Aromatic ring (lignin) & $\begin{array}{c}\text { (Bodîrlău \& Teacă, 2009; Gonultas \& } \\
\text { Candan, 2018) }\end{array}$ & $1511 / 78.06$ & $1508 / 89.24$ & $1507 / 89.56$ \\
\hline $1460 \mathrm{~cm}^{-1}$ & $\begin{array}{c}\mathrm{C}-\mathrm{H} \text { asymmetric deformations in }-\mathrm{CH}_{3} \\
\text { and }-\mathrm{CH}_{2}-\end{array}$ & $\begin{array}{l}\text { (Jahan \& Mun, 2006; Huang et al., } \\
\text { 2012) }\end{array}$ & $1461 / 78.27$ & $1461 / 82.35$ & - \\
\hline $1425 \mathrm{~cm}^{-1}$ & $\mathrm{CH}_{2}$ bending cellulose & (El Hadidi, 2017) & $1426 / 77.13$ & $1420 / 83.32$ & $1418 / 78.53$ \\
\hline $1375 \mathrm{~cm}^{-1}$ & $\mathrm{CH}$ bending in cellulose & $\begin{array}{l}\text { (Poletto et al., 2012; Lionetto et al., } \\
\text { 2012; El Hadidi, 2017) }\end{array}$ & $1373 / 76.37$ & $1384 / 79.7$ & $1384 / 53.62$ \\
\hline $1335 \mathrm{~cm}^{-1}$ & $\begin{array}{l}\text { OH (plane bending in cellulose 'amorph- } \\
\text { ous') }\end{array}$ & $\begin{array}{l}\text { (Colom et al., 2003; Lionetto et al., } \\
\text { 2012; El Hadidi, 2017) }\end{array}$ & - & - & $1336 / 78.67$ \\
\hline $1316 \mathrm{~cm}^{-1}$ & $\mathrm{CH}_{2}$ wagging (crystalline cellulose) & $\begin{array}{l}\text { (Colom et al., 2003; Lionetto et al., } \\
\text { 2012; El Hadidi, 2017) }\end{array}$ & $1318 / 76.94$ & $1320 / 79.76$ & $1320 / 79.90$ \\
\hline $1269 \mathrm{~cm}^{-1}$ & guaiacyl ring, $\mathrm{C}-\mathrm{O}$ in lignin & (Pandey, 1999; Popescu et al., 2006) & $1269 / 72.91$ & $1269 / 81.77$ & - \\
\hline $1235 \mathrm{~cm}^{-1}$ & $\begin{array}{l}\text { Acetyl and carboxyl vibrations and } \mathrm{C}=\mathrm{O} \\
\text { stretching in Xylan and lignin }\end{array}$ & (Yilgor et al., 2013) & $1233 / 74.14$ & - & - \\
\hline $1159 \mathrm{~cm}^{-1}$ & $\begin{array}{l}\mathrm{C}-\mathrm{O}-\mathrm{C} \text { asymmetric stretching vibrations } \\
\text { (Carbohydrate) }\end{array}$ & $\begin{array}{l}\text { (Andriulo et al., 2016; Traoré et al., } \\
\text { 2018) }\end{array}$ & $1159 / 69.09$ & - & - \\
\hline $897 \mathrm{~cm}^{-1}$ & $\mathrm{C}-\mathrm{H}$ deformation in cellulose & (Zhou et al., 2018) & $896 / 80.09$ & $895 / 85.46$ & $863 / 89.65$ \\
\hline $806 \mathrm{~cm}^{-1}$ & $\begin{array}{l}\text { Aromatic } \mathrm{C}-\mathrm{H} \text { (out of planedeformations) } \\
\text { in lignin }\end{array}$ & $\begin{array}{l}\text { (Evans, 1991; Xing et al., 2015; } \\
\text { Traoré et al., 2018) }\end{array}$ & $806 / 81.23$ & $807 / 84.77$ & $808 / 87.07$ \\
\hline
\end{tabular}

peaks appear at $3408 \mathrm{~cm}^{-1}$ and $3527 \mathrm{~cm}^{-1}$. The band at $3527 \mathrm{~cm}^{-1}$ is related to the absorbed water bound and the intramolecular H-bond in lignin (Popescu et al., 2011b). According to a previous literature, this stretching mode of $\mathrm{H}_{2} \mathrm{O}$ molecules is caused by the high level of moisture surrounding these wood lintels (El-Hadidi \& Darwish, 2008).

The FTIR spectra of sample S2 shows a decrease in the absorbance at 2895 $\mathrm{cm}^{-1}$ and $2939 \mathrm{~cm}^{-1}$ (C-H stretching) bands, for sample S3 the band around 2890 $\mathrm{cm}^{-1}$ is disappeared and there is a decrease in absorbance at $2895 \mathrm{~cm}^{-1}$. This decrease comes as a result of the degradation of cellulose and the changes in its 


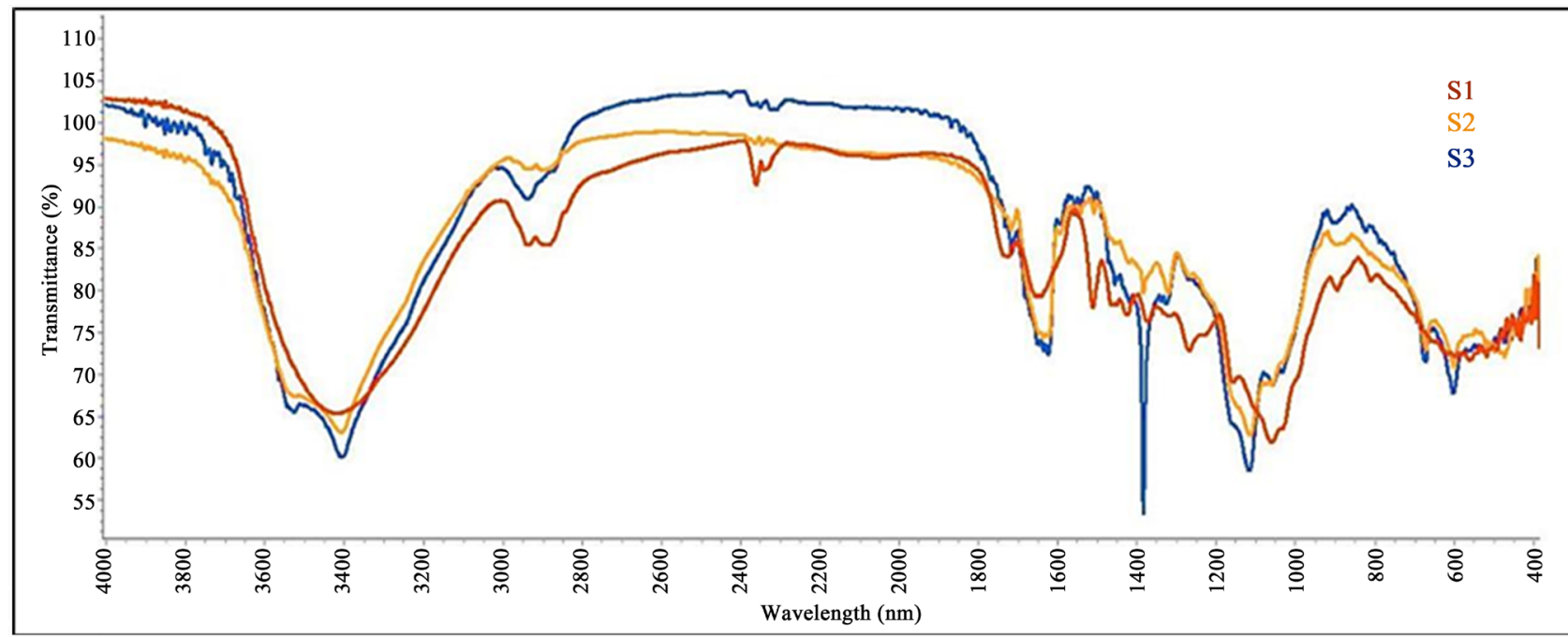

Figure 12. FTIR spectra of the control sample (S1), the window lintel in the outer portico (S2 sample), and the door lintel in the mausoleum dome chamber (S3 sample).

crystallinity level (Kubovský et al., 2020).

At the band around $1640 \mathrm{~cm}^{-1}$ ( $\mathrm{C}=\mathrm{O}$ stretching), which refers to $\mathrm{H}_{2} \mathrm{O}$ absorption, there is a remarkable increase in band intensity. This corresponds to the increase and the split in the $\mathrm{O}-\mathrm{H}$ stretching band around $3420-3527 \mathrm{~cm}^{-1}$. This band comes as a result of the water absorption from the surrounding environment. The obvious multiplication of carbonyl bands in this zone is resulting from the degradation of lignin and cellulose (El-Hadidi \& Darwish, 2008).

The band at $1739 \mathrm{~cm}^{-1}$ ( $\mathrm{C}=\mathrm{O}$ stretch in un-conjugated ketones) concerns hemicellulose. This band disappeared in the sample S2, while the absorption intensity at sample S3 decreased obviously. The decrease in this band is caused by the deterioration of the acetyl group and hemicellulose by the effect of weathering factors (Reinprecht et al., 2018; Yildiz et al., 2018; Iruela, 2020).

The bands which concern lignin were found at $1595 \mathrm{~cm}^{-1}, 1511 \mathrm{~cm}^{-1}$ and 1269 $\mathrm{cm}^{-1}$. In addition to that, the band at $1460 \mathrm{~cm}^{-1}$ concern lignin and carbohydrates (Pandey \& Pitman, 2003). All bands of lignin registered a significant decrease in absorbance. The absorption band around $1595 \mathrm{~cm}^{-1}$ (aromatic skeletal) appears in sample $\mathrm{S} 1$ as a shoulder. As for the archaeological samples, a decrease in absorption intensity was observed around the band $1595 \mathrm{~cm}^{-1}$ which appeared very weak in samples S2 and S3. According to some previous researches, the changes and the absorption decrease at this band and that may be due to the presence of water in these samples (Fors \& Richards, 2010), and also to the effect of the methoxy (O-CH) groups of the guaiacyl rings (Zhang et al., 2009).

The band around $1505-1511 \mathrm{~cm}^{-1}$ (aromatic skeletal) is used to assess the content of Lignin in wood samples. Comparing samples S2 and S3 with the S1 sample, there is a shift of this band and a remarkable decrease in intensity of the bands at $1508 \mathrm{~cm}^{-1}$ for S2 and at $1507 \mathrm{~cm}^{-1}$ for S3 which appear as very weak peaks. This decrease indicates the effect of weathering factors on the aromatic rings (Zhang et al., 2009). Previous research reported that this decrease is re- 
sulting from the methoxyl groups decrease and from the loss of syringyl units of lignin (Kubovský et al., 2020). Weathering caused a decrease in the intensity of the $1269 \mathrm{~cm}^{-1}$ band (guaiacyl ring breathing with C-O stretching) (Lionetto et al., 2012) in the archaeological samples. It was a very clear band in the control sample, but it appeared as a shoulder in the sample S2, and disappeared in the sample S3. The band at $1460 \mathrm{~cm}^{-1}$ (asymmetric $\mathrm{CH}$ deformations in lignin) (Kubovský et al., 2020) in sample S2 was observed very weak, while it was absent in sample S3.

The absorption bands around $1373 \mathrm{~cm}^{-1}, 1336 \mathrm{~cm}^{-1}, 1317 \mathrm{~cm}^{-1}, 1159 \mathrm{~cm}^{-1}$ and $897 \mathrm{~cm}^{-1}$ refer to cellulose. The cellulose band at $1373 \mathrm{~cm}^{-1}$ appeared in the control sample, while it appeared in the archaeological samples at $1384 \mathrm{~cm}^{-1}$. This band in sample S2 decreased in absorbance and appeared as a weak band. In sample S3, the band at $1384 \mathrm{~cm}^{-1}$ increased in absorbance and appeared as a very strong band. The increase in intensity in this band refers to the depolymerization of cellulose which is intimately related to the decrease or the disappearance of the lignin band around $1510 \mathrm{~cm}^{-1}$ (Genestar \& Palou, 2006).

There was a decrease in the band intensity that was noted in the band at1425 $\mathrm{cm}^{-1}\left(\mathrm{CH}_{2}\right.$ bending cellulose, "crystallized I and amorphous cellulose") (El Hadidi, 2017). This band shifted also to lower wavelengths in the archaeological samples: it became at $1420 \mathrm{~cm}^{-1}$ in sample S2 and at $1418 \mathrm{~cm}^{-1}$ in sample S3, and that indicates the extent of the cellulose damage resulting from the weathering factors

The bands at $1335 \mathrm{~cm}^{-1}$ and at $1316 \mathrm{~cm}^{-1}$ refer to the wood cellulose, in the control sample (S1) these bands were observed as weak bands with a shoulder at $1318 \mathrm{~cm}^{-1}$. In the archaeological samples (S2, S3), these bands decreased in absorption compared with the $\mathrm{S} 1$ sample. However, these bands can be observed as two bands in sample S3 around $1320 \mathrm{~cm}^{-1}$ and $1336 \mathrm{~cm}^{-1}$, while in sample S2, only one band appeared as one peak at $1320 \mathrm{~cm}^{-1}$. Previous research stated that the decrease of absorption and the two similar bands in this area were a result of the increase of the content of the crystallized cellulose (Colom et al., 2003). The band at $1235 \mathrm{~cm}^{-1}$ ( $\mathrm{C}=\mathrm{O}$ in xylan-lignine), disappeared in samples $\mathrm{S} 2$ and $\mathrm{S} 3$ and that comes as a result of the degradation of xylan and the lignin changes (Shi et al., 2012). The peak at $1159 \mathrm{~cm}^{-1}$ (C-O-C asymmetric stretching vibrations in cellulose and hemicellulose) disappeared in samples S2 and S3. This means that there is a big loss in the degree of cellulose polymerization (breaking the chains of cellulose) (Darwish et al., 2013; Hamed et al., 2020).

The peak at $897 \mathrm{~cm}^{-1}$ (C-H deformation of cellulose) (Reinprecht et al., 2018) decreased significantly in intensity. It seems like a very weak peak in the archaeological samples (S2 and S3). This decrease indicates the decrease of the amorphous cellulose (Kubovský et al., 2020). The peaks at $806 \mathrm{~cm}^{-1}$ (the ring of benzene) decreased substantially in intensity and appeared as a very weak peak. There was a similar result in previous research which reported that the delignification from the softwood was the reason for these changes (Xing et al., 2015). 
The results and findings summary: it's so clear that the pine wood which was exposed in its surface to weathering factors with high levels of moisture, was damaged more than the pine wood that was exposed to normal levels of relative humidity. We find that the outer surface of the wood exposed to high levels of moisture became very brittle, pale, swollen, and its fibers lack bonding especially in the areas nearby the walls.

The FTIR spectra showed that the main chemical components of the two archaeological wood samples were remarkably affected by the weathering Factors. In these samples, it was observed a decrease in most of the cellulose, hemicellulose, and lignin bands. There are some other bands that have disappeared such as the bands at $1235 \mathrm{~cm}^{-1}$ and at $1159 \mathrm{~cm}^{-1}$ for the two samples (S1 and S2). For the bands around $1269 \mathrm{~cm}^{-1}, 1460 \mathrm{~cm}^{-1}$, and $2890 \mathrm{~cm}^{-1}$, they disappeared in sample S3. Also, the band around $1739 \mathrm{~cm}^{-1}$ disappeared in sample S2. The FTIR analysis results indicate that the door lintel, surrounded by high levels of moisture in the mausoleum dome chamber, is the most affected by the weathering factors. It appears that the decrease in most of the cellulose, hemicellulose, and lignin bands was more than in the window lintels of the outer portico which are surrounded by low levels of humidity. There is a remarkable increase at the 1384 $\mathrm{cm}^{-1}$ band which is resulted from the depolymerization of cellulose (Genestar \& Palou, 2006). It is observed also that the bands of lignin at $1460 \mathrm{~cm}^{-1}, 1268 \mathrm{~cm}^{-1}$, and $1235 \mathrm{~cm}^{-1}$ disappeared and this explains the obvious detachment between the wood surface fibers.

\section{Conclusion}

In general, the evaluation results of the archaeological wood deterioration are very important to identify the deterioration patterns and the changing of environmental conditions surrounding this archaeological wood. Also, this evaluation enables us to use the appropriate methods and materials of treatment that must be selected according to the status of the wooden artifacts (El Hadidi, 2017).

In the archaeological and historical buildings, all the outdoor wooden artifacts are exposed to the influence of the surrounding weathering factors. It is remarkable in this research that all of the outdoor lintels in the mausoleum of Fatma Khatun are exposed to the directly weathering agents, but with a disparity in its amounts. Some of these lintels (the lintels of the main door in the mausoleum dome chamber) were exposed to the effect of weathering factors in the following sequence according to its amounts: (Moisture of "groundwater and relative humidity", sunlight, and temperature). Some of other lintels (the window lintels in the outer portico and in the entry corridor of this mausoleum) were exposed to the effect of weathering factors in the following sequence according to its amounts: (sunlight, temperature, and relative humidity).

The analysis was made by using the Digital Microscope (DM), Scanning Electron Microscope (SEM), and Fourier Transform Infrared Spectra (FTIR), which 
showed that the disparity in the amounts of the weathering agents had a clear effect on the wood appearance, the wood cells, and on its main chemical components.

The wooden lintels that exposed to the weathering factors with high levels of moisture were damaged more than the wooden lintels that were exposed to high temperature and normal levels of relative humidity. We find that the surface of the wood exposed to high levels of moisture appears very brittle, pale, swollen, and its surface fibers lack bonding, especially in the areas nearby the walls. Also, the FTIR analysis results indicate that the wooden lintel which was surrounded by high levels of moisture, is the most affected by the weathering factors. The sample of this lintel showed a decrease in most of the cellulose, hemicellulose, and lignin bands. The disappearance of some lignin bands at $1460 \mathrm{~cm}^{-1}, 1268$ $\mathrm{cm}^{-1}$, and at $1235 \mathrm{~cm}^{-1}$ explains the obvious detachment between the wood surface fibers. This research contributes to change the researchers' perspective when they study the effect of weathering factors on archaeological wood because this research recommends to arrange these factors according to its amounts. In this study, we found that the arrangement of weathering agents according to their amounts was clearly reflected on the external appearance and the on main chemical compounds of archaeological pine wood.

\section{Conflicts of Interest}

The author declares no conflicts of interest regarding the publication of this paper.

\section{References}

Ali, M. (2019). The Deterioration of Domestic Wooden Surfaces of Historical Buildings in Upper Egypt (pp. 3-24). Athens: ATINER'S Conference Paper Series, No. ART20192697.

Andriulo, F. et al. (2016). Nanotechnologies for the Restoration of Alum-Treated Archaeological Wood. Applied Physics A, 122, 322. https://doi.org/10.1007/s00339-016-9833-0

Bodîrlău, R., \& Teacă, C. A. (2009). Fourier Transform Infrared Spectroscopy and Thermal Analysis of Lignocellulose Fillers Treated with Organic Anhydrides. Romanian Journal of Physics, 54, 93-104.

Colom, X. et al. (2003). Structural Analysis of Photodegraded Wood by Means of FTIR Spectroscopy. Polymer Degradation and Stability, 80, 543-549. https://doi.org/10.1016/S0141-3910(03)00051-X

Darwish, S. et al. (2013). The Effect of Fungal Decay on Ficus Sycomorus Wood. International Journal of Conservation Science, 4, 271-282.

El Hadidi, N. (2017). Decay of Softwood in Archaeological Wooden Artifacts. Studies in Conservation, 62, 83-95. https://doi.org/10.1179/2047058415Y.0000000028

El Hadidi, N., \& Darwish, S. (2014). Preliminary Study on the Different Effects of Consolidation Treatments in Heartwood and Sapwood of a Decayed Gymnosperm Wood. Egyptian Journal of Archaeological and Restoration Studies, 4, 1-11. https://doi.org/10.21608/ejars.2018.7269 
El-Hadidi, N., \& Darwish, S. (2008). The Use of Acids and Alkalis in Cleaning Archaeological Wood. International Conference on Giza through the Ages, Faculty of Archaeology, Cairo, 4-6 March 2008.

Evans, P. A. (1991). Differentiating "Hard" from "Soft" Woods Using Fourier Transform Infrared and Fourier Transform Raman Spectroscopy. Spectrochim Acta A, 47, 14411447. https://doi.org/10.1016/0584-8539(91)80235-B

Feist, W. C. (1983). Weathering and Protection of Wood. Proceedings, Seventy-Ninth Annual Meeting of the American Wood-Preservers' Association, Vol. 79, 195-205.

Feist, W. C. (1990). Outdoor Wood Weathering and Protection. In Archaeological Wood: Properties, Chemistry and Preservation (pp. 263-298). Washington DC: American Chemical Society. https://doi.org/10.1021/ba-1990-0225.ch011

Fors, Y., \& Richards, V. (2010). The Effects of the Ammonia Neutralizing Treatment on Marine Archaeological Vasa Wood. Studies in Conservation, 55, 41-54. https://doi.org/10.1179/sic.2010.55.1.41

Genestar, C., \& Palou, J. (2006). SEM-FTIR Spectroscopic Evaluation of Deterioration in an Historic Coffered Ceiling. Analytical and Bioanalytical Chemistry, 384, 987-993. https://doi.org/10.1007/s00216-005-0243-y

Gonultas, O., \& Candan, Z. (2018). Chemical Characterization and FTIR Spectroscopy of Thermally Compressed Eucalyptus Wood Panels. Maderas: Ciencia y Tecnologia, 20, 431-442. https://doi.org/10.4067/S0718-221X2018005031301

Hamed, S. A. M. (2014). Investigation of Deterioration in Archaeological Wood Used in Architectural Elements: Microscopic Study. In A. Méndez-Vilas (Ed.), Microscopy: Advances in Scientific Research and Education (Vol. 2, pp. 857-862). Badajoz: Formatex Research Center.

Hamed, S. A. M. et al. (2020). Investigating the Impact of Weathering and In-door Aging on Wood Acidity Using Spectroscopic Analyses. BioResources, 15, 6506-6525.

Han, L. et al. (2020). Even Visually Intact Cell Walls in Waterlogged Archaeological Wood Are Chemically Deteriorated and Mechanically Fragile: A Case of a 170 Year-Old Shipwreck. Molecules, 25, 1113. https://doi.org/10.3390/molecules 25051113

Henriques, D. F., \& Azevedo, A. C. B. (2018). Outdoor Wood Weathering and Protection. Construction Pathology, Rehabilitation Technology and Heritage Management, Caceres, 15-18 May 2018, 2007-2015.

Huang, Y. et al. (2012). Analysis of Lignin Aromatic Structure in Wood Based on the IR Spectrum. Journal of Wood Chemistry and Technology, 32, 294-303. https://doi.org/10.1080/02773813.2012.666316

Iruela, A. G. (2020). Effect of Degradation on Wood Hygroscopicity: The Case of a 400Year-Old Coffin. Forests, 11, 712. https://doi.org/10.3390/f11070712

Jahan, M. S., \& Mun, S. P. (2006). Characteristics of Milled Wood Lignins Isolated from Different Ages of Nalita Wood (Trema orientalis). Cellulose Chemistry and Technology, 40, 457-467.

Jankowska, A. (2015). The Study of Influence Artificial Weathering on Color Changes of Selected Wood Species from Africa. Forestry and Wood Technology, 92, 131-136.

Kubovský, I. et al. (2020). Structural Changes of Oak Wood Main Components Caused by Thermal Modification. Polymers, 12, 485. https://doi.org/10.3390/polym12020485

Lionetto, F. et al. (2012). Monitoring Wood Degradation during Weathering by Cellulose Crystallinity. Materials, 5, 1910-1922. https://doi.org/10.3390/ma5101910

Oberhofnerová, E. et al. (2017). The Effect of Natural Weathering on Untreated Wood Surface. Maderas. Ciencia y Tecnología, 19, 173-184. 
Özgenç, Ö. et al. (2018). ATR-FTIR Spectroscopic Analysis of Thermally Modified Wood Degraded by Rot Fungi. Drewno, 61, 91-105.

Pandey, K. K. (1999). A Study of Chemical Structure of Soft and Hardwood and Wood Polymers by FTIR Spectroscopy. Journal of Applied Polymer Science, 71, 1969-1975. https://doi.org/10.1002/(SICI)1097-4628(19990321)71:12<1969::AID-APP6>3.0.CO;2$\underline{\mathrm{D}}$

Pandey, K. K., \& Pitman, A. J. (2003). FTIR Studies of the Changes in Wood Chemistry Following Decay by Brown-Rot and White-Rot Fungi. International Biodeterioration \& Biodegradation, 52, 151-160. https://doi.org/10.1016/S0964-8305(03)00052-0

Poletto, M. et al. (2012). Structural Differences between Wood Species: Evidence from Chemical Composition, FTIR Spectroscopy, and Thermogravimetric Analysis. Journal of Applied Polymer Science, 126, E336-E343. https://doi.org/10.1002/app.36991

Popescu, C. et al. (2011a). Structural Analysis of Photodegraded Lime Wood by Means of FT-IR and 2D IR Correlation Spectroscopy. International Journal of Biological Macromolecules, 48, 667-675. https://doi.org/10.1016/j.ijbiomac.2011.02.009

Popescu, C. M. et al. (2006). Analytical Methods for Lignin Characterization. II. Spectroscopic Studies. Cellulose Chemistry and Technology, 40, 597-621.

Popescu, M. et al. (2011b). Evaluation of Morphological and Chemical Aspects of Different Wood Species by Spectroscopy and Thermal Methods. Journal of Molecular Structure, 988, 65-72. https://doi.org/10.1016/j.molstruc.2010.12.004

Reinprecht, L. et al. (2018). The Impact of Natural and Artificial Weathering on the Visual, Colour and Structural Changes of Seven Tropical Woods. European Journal of Wood and Wood Products, 76, 175-190. https://doi.org/10.1007/s00107-017-1228-1

Sandberg, D. (1999). Weathering of Radial and Tangential Wood Surfaces of Pine and Spruce. Holzforschung, 53, 355-364. https://doi.org/10.1515/HF.1999.059

Shi, J. et al. (2012). FTIR Studies of the Changes in Wood Chemistry from Wood Forming Tissue under Inclined Treatment. Energy Procedia, 16, 758-762. https://doi.org/10.1016/j.egypro.2012.01.122

Teles, C. D. M., \& Valle, Â. (2001). Wood Structures: Acting before Deterioration. In P. B. Lourenço, \& P. Roca (Eds.), Historical Constructions (pp. 857-866). Guimarães: University of Minho.

Traoré, M. et al. (2018). Differentiation between Pine Woods According to Species and Growing Location Using FTIR-ATR. Wood Science and Technology, 52, 487-504. https://doi.org/10.1007/s00226-017-0967-9

Unger, A. et al. (2001). Conservation of Wood Artifacts (p. 48). Heidelberg: SpringerVerlagberin.

Wiemann, M. C. (2010). Characteristics and Availability of Commercially Important Woods. In Wood Handbook-Wood as an Engineering Material, Centennial Edition (p. 1). Madison, WI: Forest Products Laboratory.

William, C. F. (1983). Weathering and Protection of Wood. Proceedings, Seventy-Ninth Annual Meeting of the American Wood-Preservers' Association, Kansas City, 17-20 April, 195-205.

Williams, R. S. (2005). Weathering of Wood. In Handbook of Wood Chemistry and Wood Composites (p. 167). Boca Raton, FL: CRC Press.

Xing, D. et al. (2015). Effect of Artificial Weathering on the Properties of Industrial-Scale Thermally Modified Wood. BioResources, 10, 8238-8252.

https://doi.org/10.15376/biores.10.4.8238-8252

Yildiz, S. et al. (2018). The Effects of Natural Weathering on the Properties of Heat- 
Treated Alder Wood. BioResources, 6, 2504-2521.

Yilgor, N. et al. (2013). Evaluation of Fungal Deterioration in Liquidambar orientalis Mill. Heartwood by FT-IR and Light Microscopy. BioResources, 8, 2805-2826. https://doi.org/10.15376/biores.8.2.2805-2826

Zhang, J. et al. (2009). Weathering of Copper-Amine Treated Wood. Applied Surface Science, 256, 842-846. https://doi.org/10.1016/j.apsusc.2009.08.071

Zhou, Y. et al. (2018). Degradation Features of Archaeological Wood Surface to Deep Inside a Case Study on Wooden Boards of Marquis of Haihun's Outer Coffin. Wood Research, 63, 419-430. 